\title{
Hubungan Tingkat Pengetahuan Dengan Sikap Perawat Tentang Perawatan Paliatif
}

\author{
${ }^{1}$ Rosmin Ilham, ${ }^{2}$ Sinta Mohammad ${ }^{3}$ Muh Nur Syukriani. Yusuf \\ ${ }^{1}$ Sekolah Tinggi Ilmu Kesehatan Tanawali Persada Takalar \\ ${ }^{2,3}$ Program Studi Ilmu Keperawatan Fakultas Olahraga dan Kesehatan Universitas Negeri Gorontalo \\ Email: rosmin_ilham@yahoo.com
}

\begin{abstract}
Abstrak
Perawatan paliatif adalah bentuk pelayanan yang bertujuan memperbaiki kualitas hidup pasien dan keluarga dari penyakit yang dapat mengancam jiwa, dengan pengetahuan yang baik maka sikap perawat dalam memberikan pelayanan perawatan paliatif kepada pasien dan keluarga menjadi lebih baik. Penelitian ini bertujuan untuk menganalisis hubungan tingkat pengetahuan dengan sikap perawat tentang perawatan paliatif di RSUD. Prof. Dr. H. Aloei Saboe Kota Gorontalo. Penelitian ini menggunakan Survei analitik dengan desain cross sactional Populasi dalam penelitian ini adalah semua perawat yang bertugas d ICU, Hemodialisis (HD) dan perawatan bedah sebanyak 51 responden. Tekhnik pengambilan sampel menggunakan total sampling dengan jumlah sampel 51 responden. Hasil penelitian menunjukkan bahwa sebahagian besar responden yang memiliki pengetahuan baik sebanyak 35 responden $(68,63 \%)$ dan sikap dengan kategori baik sebanyak 37 responden $(72,55 \%)$. Kesimpulan dalam penelitian ini adalah terdapat hubungan tingkat pengetahuan dengan sikap perawat tentang perawatan paliatif di RSUD. Prof. Dr. H. Aloei Saboe Kota Gorontalo Tahun 2019. Diharapkan penelitian ini dapat menambah wawasan dan pengalaman dalam mengaplikasikan pengetahuan yang diperoleh dibangku kulia, serta hasil penelitian ini dapat digunakan untuk mengembangkan penelitian dalam lingkup yang sama.
\end{abstract}

Kata Kunci: Pengetahuan, Sikap, Perawatan Paliatif

\begin{abstract}
Palliative care is a service that aims to improve the quality of life of patients and familes from life-threatening diseases, with good knowledge, the attitude of nurses in providing palliative care services to patients and families is better. This study aims to analyze the relationship between the level of knowledge and the attitudes of nurses about palliative care in Prof. Dr. H. Aloei Saboe Hospital, Gorontalo City. This study used an analytical survey with cross-sectional design, the sample in this study were all nurses on duty in ICU, hemodialist units and surgical care as many as 51 respondents. The results showed that most respondents who had good knowledge were 35 respondents $(68.63 \%)$ and attitudes with good categories were 37 respondents $(72.55 \%)$. The conclusion in this study is that there is a relationship between the level of knowledge and the attitude of nurses about palliative care at the RSUD Prof. Aloei Saboe in 2019.
\end{abstract}

Keywords: Knowledge, Attitude, Palliative Care

\section{PENDAHULUAN}

Perawatan paliatif adalah bentuk pelayanan yang bertujuan memperbaiki kualitas hidup pasien dan keluarga dari penyakit yang dapat mengancam jiwa, melalui pencegahan dan peniadaan dengan cara identifikasi dini, penilaian yang tertib, penanganan nyeri dan masalah-masalah lain yaitu fisik, psikososial dan spiritual.

Berdasarkan prevalensi WHO tahun 2011 menunjukkan bahwa dari 29 miliar kasus paliatif sebanyak 20,4 miliar kasus membutuhkan pelayanan paliatif. Menurut profil WHO tahun 2011 menyebutkan bahwa tingkat kematian di Indonesia mencapai 1.064.000 (Kementrian Kesehatan RI, 2012). Jumlah pasien dengan penyakit yang belum dapat disembuhkan baik pada dewasa dan anak seperti penyakit kanker, penyakit degeneratif, penyakit paru obstruksi kronis, gagal jantung/heart failure, penyakit genetika, stroke, dan penyakit infeksi seperti HIV/AIDS terus meningkat setiap tahunnya (KEPMENKES RI NOMOR: 812, 2007). Pasien tersebut memerlukan perawatan paliatif, di samping kegiatan promotif, preventif, kuratif, dan rehabilitatif.

Penerapan perawatan paliatif care di Indonesia sendiri memang belum banyak. Salah satu tantangannya adalah terkait bagaimana para tenaga kesehatan memandang persoalan kematian pasien. Masih banyak rumah sakit yang belum 
memahami bahwa seharusnya pasien diberikan paliatif, terutama untuk pasien dengan stadium terminal (Sulaiman, 2016). Berdasarkan prevalensi di Kota Gorontalo menunjukan bahwa jumlah pasien yang mengalami penyakit yang tidak dapat lagi disembuhkan dalam 1 tahun terakhir mengalami peningkatan, mulai dari penyakit kanker $2,1 \%$, stroke 10,8\%, HIV/AIDS $60 \%$, dan penyakit ginjal kronis $4.0 \%$ (Riskesdas, 2018). Sehingga perlu sekali adanya perawatan paliatif.

Perawatan paliatif sangat dibutuhkan oleh pasien yang mengalami penyakit yang tidak dapat disembuhkan lagi. Perawatan paliatif sesuai untuk semua pasien dengan diagnosis kondisi yang mengancam nyawa. Layanan perawatan paliatif paling efektif ketika diintegrasikan ke dalam layanan perawatan yang spesifik (seperti rumah sakit, perawatan rumah, bantuan hidup, panti jompo, dan sebagainya). Hal ini membutuhkan pelatihan dasar perawatan paliatif untuk praktisi di segala bidang dalam layanan primer, seperti dengan membuat pola rujukan dan akses untuk perawatan spesialis paliatif dan tim perawatan paliatif formal (Champbell, dkk, 2014).

Berdasarkan hasil wawancara yang dilakukan pada tanggal 20 Februari 2019 dengan 5 orang perawat di ruang ICU, HD, dan di ruang SP2KP Bedah Lt2 di RSUD. Prof. Dr. H. Aloei Saboe Kota Gorontalo, ditemukan bahwa 2 dari 5 orang perawat tidak memahami tentang perawatan paliatif. Sedangkan 3 orang perawat lainnya mengetahui tentang perawatan paliatif. Perawat di ICU dan SP2KP Bedah Lt2 mengatakan mereka memberikan tindakan yang baik sesuai dengan SOP, perawat sangat memperhatikan keadaan kebutuhan pasien yang dibutuhkan melalui pemberian pelayanan keperawatan, terutama pada pasien yang penyakitnya sudah tidak bisa lagi disembuhkan. Untuk pelatihan, perawat di ICU, Hemodialisis (HD) dan di SP2KP Bedah Lt2 mengatakan mereka selalu mengikuti pelatihan, setiap ada jadwal untuk pelatihan mereka selalu mengikuti tetapi untuk pelatihan perawatan paliatif mereka belum pernah mengikuti. Hasil penelitian sebelumnya yang dilakukan oleh Eka Yulia Fitri (2017) menemukan adanya hubungan antara pengetahuan dengan sikap perawat tentang perawatan paliatif di RS Bhayangkara Palembang.

\section{METODE PENELITIAN}

Penelitian ini dilaksanakan di ruang ICU, HD, dan diruang SP2KP Bedah Lt2 RSUD. Prof. H. Aloei Saboe Kota Gorontalo dari tanggal 26 juni sampai dengan 29 juni 2019. Penelitian ini menggunakan desain Survei Deskriptif. Populasi sebanyak 1992 responden, Dengan tehnik pengambilan sampel menggunakan random sampling. Sampel pada penelitian ini berjumlah 95 responden. Penelitian ini menggunakan Survei analitik dengan desain cross sactional. Populasi dalam penelitian ini adalah semua perawat yang bertugas d ICU, HD dan perawatan bedah sebanyak 51 responden. Tekhnik pengambilan sampel menggunakan total sampling dengan jumlah sampel 51 responden.

\section{HASIL PENELITIAN}

Tabel 1. Karakteristik frekuensi responden berdasarkan usia

No

4

Umur

17-25 Tahun
26-35 Tahun
36-45 Tahun
46-55 Tahun

Total (n)

$\begin{array}{cc}8 & 15,69 \% \\ 31 & 60,78 \% \\ 11 & 21,57 \% \\ 1 & 1,96 \%\end{array}$

Presentasi (\%)

$100.00 \%$ 
Vol. 1, No. 2, July 2019

Jambura Nursing Journal

pISSN: 2654-2927, eISSN: 2656-4653

Tabel 2. Karakteristik frekuensi responden berdasarkan jenis kelamin

\begin{tabular}{cccc}
\hline No & Jenis Kelamin & (n) & Presentasi $(\boldsymbol{\%})$ \\
\hline 1 & Laki-Laki & 11 & $21,57 \%$ \\
2 & Perempuan & 40 & $78,43 \%$ \\
\hline & Total & $\mathbf{5 1}$ & $\mathbf{1 0 0 , 0 0 \%}$ \\
\hline
\end{tabular}

Tabel. 3 Karakteristik frekuensi responden berdasarkan lama kerja

\begin{tabular}{cccc}
\hline No & Lama Bekerja & (n) & Presentasi $(\boldsymbol{\%})$ \\
\hline 1 & 0-5 Tahun & 14 & $27,45 \%$ \\
2 & 6-10 Tahun & 20 & $39,22 \%$ \\
3 & 11-15 Tahun & 11 & $21,57 \%$ \\
4 & 16-20 Tahun & 5 & $9,80 \%$ \\
5 & $>$ 20 Tahun & 1 & $1,96 \%$ \\
\hline
\end{tabular}

Tabel 4. Karakteristik frekuensi responden berdasarkan pendidikan

\begin{tabular}{cccc}
\hline No & Pendidikan & (n) & Presentasi (\%) \\
\hline 1 & Diploma III & 27 & $52,94 \%$ \\
2 & DIploma IV & 2 & $3,92 \%$ \\
3 & Sarjana & 10 & $19,61 \%$ \\
4 & Sarjana+Ners & 11 & $21,57 \%$ \\
5 & Magister & 1 & $1,96 \%$ \\
\hline & Total & $\mathbf{5 1}$ & $\mathbf{1 0 0 , 0 0 \%}$ \\
\hline
\end{tabular}

Tabel 5. Distribusi frekuensi tingkat pengetahuan responden

\begin{tabular}{cccc}
\hline No & Pengetahuan & (n) & Presentasi (\%) \\
\hline 1 & Baik & 35 & $68,63 \%$ \\
2 & Kurang Baik & 16 & $31,37 \%$ \\
\hline & Total & $\mathbf{5 1}$ & $\mathbf{1 0 0 , 0 0 \%}$ \\
\hline
\end{tabular}

Tabel 6. Distribusi frekuensi sikap responden

\begin{tabular}{cccc}
\hline No & Sikap & (n) & Presentasi (\%) \\
\hline 1 & Baik & 37 & $72,55 \%$ \\
2 & Kurang Baik & 14 & $27,45 \%$ \\
\hline \multicolumn{2}{c}{ Total } & $\mathbf{5 1}$ & $\mathbf{1 0 0 , 0 0 \%}$ \\
\hline
\end{tabular}

Tabel 7. Tabulasi silang hubungan variabel tingkat pengetahuan dengan sikap perawat tentang perawatan paliatif.

\begin{tabular}{|c|c|c|c|c|c|}
\hline \multirow{3}{*}{ Pengetahuan } & \multicolumn{4}{|c|}{ Sikap } & \multirow{3}{*}{$p$ value } \\
\hline & \multicolumn{2}{|c|}{ Baik } & \multicolumn{2}{|c|}{ Kurang Baik } & \\
\hline & n & $\%$ & n & $\%$ & \\
\hline Baik & 29 & 56,9 & 6 & 11,8 & \\
\hline Kurang Baik & 8 & 15,7 & 8 & 15,7 & 0,015 \\
\hline Total & 37 & 72,5 & 14 & 27,5 & \\
\hline
\end{tabular}


PEMBAHASAN

Berdasarkan hasil penelitian pada tabel

5 menunjukkan bahwa yang memiliki pengetahuan dengan kategori baik adalah sebanyak 35 responden $(68,63 \%)$. Hal ini disebabkan karena pasien yang dirawat oleh responden adalah sebahagian besar pasien dengan penyakit terminal yang membutuhkan perawatan paliatif, dimana responden memiliki lama kerja 6-10 tahun sebanyak 16 responden $(31,37 \%), 11-15$ tahun sebanyak 6 responden $(11,76 \%)$, dan 16-20 sebanyak 7 responden $(13,72 \%)$ sehingga asumsi peneliti pengetahuan baik itu disebabkan oleh karena lama kerja. Lama kerja dan pegalaman dalam kesehariannya rutin merawat pasien dengan penyakit terminal tersebut menjadi komponen yang menunjang pengetahuan perawat dalam memberikan perawatan paliatif.

Lama bekerja seseorang akan menentukan banyak pengalaman yang dipatkannya. Sunaryo (2010) mengemukakan bahwa tingkat kematangan dalam berpikir dan berperilaku dipengaruhi oleh pengalaman kehidupan sehari-hari. Hal ini menunjukkan bahwa semakin lama masa kerja akan semakin tinggi tingkat kematangan seseorang dalam berpikir sehingga lebih meningkatkan pengetahuan yang dimiliki. Pernyataan ini sejalan dengan penelitian Rachmawati dan Nasution (2011) yang mengatakan bahwa lamanya masa kerja seseorang dapat menambah wawasan dan pengalamannya, namun tidak bisa dijadikan indikator untuk kualitas kerjanya.

Hal ini sesuai dengan teori Notoadmojo (2010), yang menyatakan bahwa pengalaman seseorang sangat mempengaruhi pengetahuan, semakin banyak pengalaman seseorang tentang suatu hal, maka akan semakin bertambah pula pengetahuan seorang akan hal tersebut. Pengalaman adalah memperoleh kebenaran pengetahuan dengan cara mengulang kembali pengetahuan yang diperoleh dalam memecahkan masalah yang dihadapi pada masa lalu dan dapat digunakan dalam upaya memperoleh pengetahuan

Menurut Nugroho (2017), ia
menyatakan bahwa masa kerja erat dengan pengalaman hidup yang didapatkan. Masa kerja yang singkat, maka peluang untuk mendapat pengalaman akan semakin sedikit jika dibandingkan dengan masa kerja yang panjang. Hal ini sejalan dengan penelitian yang dilakukan oleh Agnes Trigiarti (2018), menunjukan bahwa pengetahuan dapat dipengaruhi oleh lama kerja dan pengalaman. Hal ini sesuai dengan temuan pada penelitian Alshaik (2015) yaitu perawat mendapatkan pengetahuan mengenai perawatan paliatif melalui pengalaman dan tanpa disadari perawat melakukan perawatan paliatif dalam praktek sehari-hari.

Notoadmojo (2012), mengemukakan bahwa pengalaman seseorang tentang berbagai hal dapat diperoleh dari lingkungan kehidupan dalam proses perkembangannya, misalnya seseorang mengikuti kegiatan-kegiatan yang mendidik, seperti seminar dan berorganisasi, sehingga dapat memperluas pengalamannya, karena dari berbagai kegiatan-kegiatan tersebut, informasi tentang suatu hal dapat diperoleh.

Hasil penelitian didapatkan bahwa dari 35 responden $(68,6 \%)$ yang memiliki pengetahuan dengan kategori baik, yang berpendidikan D3 sebanyak 19 responden $(37,25 \%)$, pendidikan D4 sebanyak 1 responden (1,96\%), S1 sebanyak 3 responden $(5,88)$, S1Ners sebanyak 11 responden $(21,56 \%)$, dan pendidikan S2 sebanyak 1 responden $(1,96 \%)$. Menurut asumsi peneliti bahwa pengetahuan responden sebahagian besar baik, hal ini disebabkan oleh pendidikan. Menurut Wawan (2010), tingkat pendidikan dapat menentukan tingkat kemampuan seseorang dalam memahami dan menyerap pengetahuan yang telah diperoleh. Umumnya, pendidikan mempengaruhi suatu proses pembelajaran, semakin tinggi tingkat pendidikan semakin baik tingkat pengetahuannya.

Hal ini sesuai dengan teori Mubarak (2011) yang mengatakan semakin tinggi pendidikan seseorang, semakin mudah pula 
mereka menerima informasi, dan pada akhirnya pengetahuan yang dimilikinya akan semakin banyak. Hannula (2009) menyebutkan bahwa pendidikan berfungsi sebagai sarana meningkatkan pengetahuan, wawasan, dan ketrampilan individu dalam rangka mengembangkan potensi diri.

Responden yang memiliki pengetahuan yang kurang baik sebanyak 16 responden (31,3\%), hal ini disebabkan oleh karena responden lebih banyak merawat pasien dengan kasus bedah umum sehingga kurang pasien yang membutuhkan perawatan paliatif. Menurut asumsi peneliti bahwa dengan kuragnya kasus pasien yang membutuhkan perawatan paliatif maka pengalaman responden juga kurang. Selain pengalaman, pelatihan juga mempengaruhi tingkat pengetahuan responden, dimana hasil penelitian menunjukkan bahwa $100 \%$ responden belum mengikuti pelatihan tentang perawatan paliatif

Menurut teori Danim (2008), pelatihan adalah teknik belajar yang melibatkan pengamatan individual pada pekerjaan dan penentuan umpan balik untuk memperbaiki kinerja atau mengkoreksi kesalahan. Pelatihan yang didapakan seseorang akan menambah pengetahuan dan skill dalam membantu pasien yang dalam keadaan gawat darurat. Hal ini sejalan dengan yang dikemukakan oleh Joeharno (2011) bahwa pelatihan yang diselenggarakan kepada tenaga kesehatan memberi hubungan terhadap peningkatan pengetahuan dalam memberikan pelayanan kepada pasien di rumah sakit.

\section{Sikap Perawat}

Berdasarkan hasil penelitian pada tabel 6 menunjukkan bahwa sebagian besar responden atau perawat yang memiliki sikap yang baik sebanyak 37 responden $(72,55 \%)$, dan yang memiliki sikap yang kurang baik sebanyak 14 responden $(27,45 \%)$. Hal ini disebabkan dimana pasien yang dirawat adalah pasien yang rutin menjalani perawatan sehingga interaksi bertemu lebih banyak dan memberikan kesediaan dalam memberikan perawatan paliatif. Sementara responden yang memilki sikap kurang baik disebababkan oleh pasien yang tidak tetap atau berganti-ganti sehingga interaksi bertemu lebih kurang. Hal ini sejalan dengan penelitian oleh Yuke Kiran (2017), bahwa terbentuknya sikap positif dari perawat dapat dipengaruhi oleh interaksi antar sesama perawat, karena sikap terbentuk dengan interaksi terjadi saling tukar informasi mengenai hal yang berhubungan dengan pelaksanaan asuhan keperawatan, perawat mau memperhatikan kebutuhan klien, mengerjakan dan menyelesaikan yang diberikan serta mengajak orang lain untuk mengerjakan atau mendiskusikan suatu masalah.

Sikap adalah respon tertutup seseorang terhadap stimulus atau objek tertentu, yang sudah melibatkan faktor pendapat dan emosi yang bersangkutan. Sikap merupakan kesiapan atau kesediaan untuk bertindak, dan bukan merupakan pelaksanan motif tertentu (Notoatmodjo, 2010). Sikap mendukung yang ditunjukkan berhubungan dengan faktor-faktor yang mempengaruhi sikap seperti yang diutarakan oleh Wawan (2010), Pertama, pengaruh orang lain yang dianggap penting. Pada umumnya individu cenderung memiliki sikap yang konformis. Kedua, pengaruh kebudayaan telah menanamkan garis pengarah sikap kita terhadap berbagai masalah. Dan yang terakhir yaitu faktor emosional, terkadang suatu bentuk sikap merupakan pernyataan yang didasari emosi.

Sikap perawat kurang baik disebabkan karena tidak adanya program pelatihan perawatan paliatif. Penelitian oleh Ayed (2015) menunjukkan bahwa 6,2\% responden mempunyai sikap yang mendukung terhadap perawatan paliatif. Sikap terhadap perawatan paliatif dipengaruhi oleh kualifikasi pendidikan, pengalaman, dan pelatihan tentang perawatan paliatif yang diterima oleh perawat.

Menurut teori Wawan (2010) yaitu sikap memiliki berbagai tingkatan, yang pertama menerima (receiving), kedua merespon (responding), ketiga menghargai (valuing) 
dan terakhir bertanggung jawab (responsible) yaitu bertanggung jawab atas segala yang dipilihnya dengan segala resiko yang mungkin akan terjadi. Adapun faktor lain yang dapat mempengaruhi sikap adalah pengalaman, menurut Azwar (2010), untuk dapat menjadi dasar pembentukan sikap, pengalaman pribadilah haruslah meninggalkan kesan. Karena itu, sikap akan lebih mudah terbentuk apabila pengalaman pribadi tersebut dalam situasi yang melibatkan faktor emosional. Hal ini sejalan dengan penelitian yang dilakukan oleh Eka Yulia Firi (2017), menyatakan bahwa pengalaman kerja tanpa melihat waktu lama bekerja dapat mempengaruhi sikap perawat.

\section{Hubungan Pengetahuan dengan Sikap Perawat tentang Perawatan Paliatif}

Berdasarkan hasil analisis dengan uji chi square diperoleh nilai Probability Value $(P$-Value) variabel tingkat pengetahuan dengan sikap perawat sebesar 0,015 . Nilai signifikasi ini masih lebih kecil dibandingkan dengan nilai alpha yang digunakan $(0,05)$ sehingga Ha diterima, dengan demikian dapat disimpulkan bahwa pada tingkat kepercayaan $95 \%$ terdapat hubungan yang signifikan tingkat pengetahuan perawat dengan sikap perawat tentang perawatan paliatif di RSUD. Prof. Dr. H. Aloei Saboe Kota Gorontalo.

Dari hasil presentasi diatas menunjukkan bahwa yang memiliki pengetahuan yang baik sebanyak 35 responden $(68,63 \%)$, dan yang memiliki pengetahuan yang kurang baik sebanyak 16 responden $(31,37 \%)$, sementara sikap, dimana responden yang memiliki sikap yang baik adalah sebanyak 37 responden $(72,55 \%)$, dan yang memiliki sikap yang kurang baik sebayak 14 responden $(27,45 \%)$.

Hasil dari penelitian diatas menunjukkan bahwa terdapat hubungan yang signifikan antara pengetahuan dan sikap. Hal ini sejalan dengan teori yang diungkapkan oleh Dahlan (2009) bahwa nilai positif menunjukkan bahwa semakin baik tingkat pengetahuan perawat tentang perawatan paliatif, maka semakin baik pula sikap perawat terhadap pasien. Menurut Notoatmodjo (2010) pengetahuan memegang peranan penting dalam penentuan sikap yang utuh (total attitude). Sikap dapat diubah dengan cara meningkatkan pengetahuan. Sikap negatif cenderung menurun sebagai akibat dari meningkatnya tingkat pengetahuan.

Penelitian ini juga sejalan dengan penelitian yang dilakukan oleh Fitriana Wulandari (2010) yang melakukan hubungan tingkat pengetahuan perawat tentang perawatan paliatif dengan sikap terhadap penatalaksanaan pasien dalam perawatan paliatif di RS. Dr. Moeardi Surakarta bahwa semakin tinggi tingkat pengetahuan perawat tentang perawatan paliatif, semakin baik pula sikap perawat terhadap penatalaksanaan pasien dalam perawatan paliatif. Tingkat pengetahuan dan sikap perawat yang baik dapat diperoleh dari pengalaman, dan pelatihan. Semakin lama perawat bekerja, semakin meningkat pula pengalamannya bekerja diberbagai macam ruangan melalui program rotasi kerja. Rotasi kerja memperluas pengalaman dan kemampuan perawat, dengan pengalaman tersebut akan meningkatkan kemampuan baik pengetahuan (Knowledge) maupun keterampilan (skill).

\section{KESIMPULAN}

Dari penelitian ini menunjukan bahwa terdapat hubungan antara tingkat pengetahuan dengan sikap perawat tentang perawatan paliatif di RSUD Prof. Dr. H. Aloei Saboe Gorontalo dengan p-value 0.015

\section{DAFTAR PUSTAKA}

Agnis Tri Giatri. 2018. Gambaran Pengetahuan Perawat Tentang Perawatan Paliatif Pada Pasien Kanker Di RSUD DR. MOEWARDI

Ayed, Ahmad., Sayej, Sumaya., Harazneh, Lubna., Fashafsheh, Imad., Eqtait Faeda. (2015). The Nurses' Knowledge and Attitudes towards the Palliative Care. Journal of Education and 
Practice www.iiste.org ISSN 22221735 (Paper) ISSN 2222-288X (Online) Vol.6, No.4, 2015

Azwar, S. (2010). Sikap Manusia Teori dan Pengukurannya. Yogyakarta: Pustaka

Danim, Sudarwan. (2008). Kinerja Staf dan Organisasi Perspektif Pendidikan, Pelatihan, Pengembangan dan Kewidyaisaraan Bebasis Kinerja. Bandung: Pustaka Setia

Eka Yulia Fitri. 2017. Gambaran Pengetahuan, Sikap, dan Tindakan Perawatan Paliatif Di RS Bhayangkara Palembang.Jurnal Implikasi Perawatan Paliatif pada Bidan Kesehatan

Margaret L.Campbell, dkk. 2014. Nurse to Nurse Perawatan Paliatif. Jakarta : Salemba Medika

Mubarak, W. (2011). Promosi Kesehatan untuk Kebidanan. Jakarta: Salemba Medika

Sunaryo. (2010). Psikologi Untuk Pendidikan. Jakarta: EGC

Notoadmodjo. 2010. Pendidikan dan Perilaku Kesehatan. Jakarta: Rineka Cipta

Nugroho Fathi Luthfi. 2017. Gambaran Tingkat Pengetahuan Perawat Tentang Bantuan Hidup Dasar (BHD) Di Bangsal Beda Beda Dan Bangsal Penyakit Dalam RSUD Wates. Yogyakarta: Sekolah Tinggi Ilmu Kesehatan Jendral Acmad Yani Yogyakarta

Joeharno. (2011). Pengguna Jasa Pelayanan Rumah Sakit. Jakarta. Salemba Medica

Kementrian Kesehatan RI. 2017. Pusat Data dan Informasi. Jakarta Selatan KEPMENKES RI NOMOR : 812/MENKES/SK/VII/2007. Tentang kebijakan perawatan paliatif, Menteri Kesehatan Republik Indonesia.

Wawan, A. 2010. Teori dan Pengukuran Pengetahuan, Sikap dan Perilaku Manusia. Yogyakarta: Nuha Medika.

Wulandari, Fitriana. (2012). Hubungan Tingkat Pengetahuan Perawat Tentang Perawatan Paliatif dengan
Sikap terhadap Penatalaksanaan Pasien dalam Perawatan Paliatif di Rumah Sakit Dr. Moewardi Surakarta. Universitas Muhammadiyah Surakarta

Wawan, A. 2010. Teori dan Pengukuran Pengetahuan, Sikap dan Perilaku Manusia. Yogyakarta: Nuha Medika.

Yuke Kiran. (2017) Pengetahuan dan Sikap dalam Memenuhi Kebutuhan Psikologis dan Spritual Klien Terminal. Jurnal Pendidikan Keperawatan Indonesia;3(2):182-189 